\title{
IDH2 NP_002159.2:p.R140Q
}

National Cancer Institute

\section{Source}

National Cancer Institute. IDH2 NP 002159.2:p.R140Q. NCI Thesaurus. Code C160661.

A change in the amino acid residue at position 140 in the isocitrate dehydrogenase

[NADP], mitochondrial protein where arg inine has been replaced by glutamine. 